Bull. Fac . Agric., Cairo Univ., 69: 53-61(2018).

\title{
GENETIC BEHAVIOR OF GOSSYPOL CONTENT, SEED TRAITS AND YIELD COMPONENTS IN AN EGYPTIAN COTTON CROSS
}

(Received:15.1.2018)

\author{
By \\ Aziza M. M. Sultan \\ Cotton Research Institute, Agriculture Research Center, Giza, Egypt
}

\begin{abstract}
The present investigation aimed to study the genetic behavior of gossypol content in seeds as well as seed traits and yield traits of cotton. In addition, correlation between gossypol percentage and four seed traits (seed index, seed size, fuzz colour and fuzz distribution) and multiple regression analysis were performed to determine the variables of high contribution to the total variance of gossypol content in seeds. The marterials used included the $\mathrm{P}_{1}, \mathrm{P}_{2}, \mathrm{~F}_{1}, \mathrm{~F}_{2}$ and $\mathrm{F}_{3}$ generations for the cross Giza 45 x BBB line at Sakha Agric. Res. Station during 2014 through 2017 seasons. Over dominance was observed for all the studied traits, except for seed size and fuzz colour which showed partial dominance in the $\mathrm{F}_{2}$ generation. Inbreeding depression was positive and significant for seed yield, lint yield and fuzz distribution, while it was negative and significant for gossypol \%, seed index and lint index in the $\mathrm{F}_{2}$ generation. Inbreeding depression in the $\mathrm{F}_{3}$ generation was negative and significant for gossypol $\%$ and seed index, while it was positive and significant for fuzz distribution on seed and lint $\%$. Scaling test indicated that $\mathrm{C}$ and $\mathrm{D}$ values deviated from zero for most studied traits, indicating the presence of non- allelic interaction. Additive gene effects were significant for most studied traits, except for seed cotton yield, lint yield and lint \%. Dominance and epistasis genetic effects were important in the inheritance of most studied traits. Results indicated that additive and dominance as well as some types of epistasis effects played an important role in the inheritance for most studied traits. The relationships between seed index and seed size, seed size and fuzz distribution were positive and significant, while they were negative and significant between gossypol percentage and fuzz distribution, seed index and fuzz colour, seed size and fuzz colour. Fuzz distribution was the highest contributor for total variance of gossypol percentage in all generations. It could be concluded that fuzz distribution was the main trait responsible for most of the variance of the gossypol percentage.
\end{abstract}

Key words: cotton, gossypium barbadense, gossypol content, yield, type of gene action correlation coefficients, regression analysis.

\section{INTRODUCTION}

Improvements of yield, fiber quality and seed components of cotton varieties are considered the main goals of cotton breeders for both human and animal consumption. Cotton contains gossypol as a polyphenolic compound that is an integral part of the cotton plants self defense system against insect pests. However, the compound is toxic to animals, which limits the usefulness of cotton seed as animal feed. Upland cotton seed usually contains from 0.6 to $2 \%$ gossypol (Lusas and Jividen, 1987). Mohamed (2003) reported that gossypol content for brown cotton seed is higher $(5.33 \mathrm{mg} / \mathrm{g}$ ) compared with both Giza 80 and Giza 89 (4.04 and $4.14 \%$ ) respectively. Mohamed and Hegazy
(2008) revealed that Giza 70 exhibited special behavior; it attained the highest content of gossypol in cotton seed. Mohamed (2015) reported the predominance of dominance genetic variance in the inheritance of the gossypol content. El-Disouqi et al. (2000) stated that additive gene effects were significant and positive for cotton seed yield and lint yield per plant. They also reported that epistatsis components were greater in magnitude than additive or dominance components for most studied traits. El-Disouqi and Zeina (2000) reported that the none allelic interactions govern most of the studied traits. Soliman (2003) found that all types of gene effects were significant for yield. Dominance and epistatic were higher in 
magnitude than additive effects in some traits.

The epistatic component dominance $\mathrm{x}$ dominance was quite positive and highly significant. Over dominance appeared to be controlling most studied traits in the $\mathrm{F}_{1}$ and the $\mathrm{F}_{2}$ generations Abou El-Yazied et al.,(2008). Nazmey (2012) found that additive gene effects were positive and significant for lint index, seed and lint yield per plant, and that dominance $\mathrm{x}$ dominance epistatic effects played important role in the inheritance of all yield component traits. Sultan (2017) reported that the epistasis type of additive $\mathrm{x}$ additive was significant for seed and lint yield and seed index. The epistasis type of dominance $\mathrm{x}$ dominance was positive and significant for seed index, while it was negative and significant for lint percentage and lint index, indicating that both additive and non additive gene effects controlled the genetic system for seed and lint yield. Dominance effects were highly significant and positive for lint yield per plant, while they were negative for lint $\%$, seed index and lint index.

The objectives of this investigation were: (1) to estimate heterosis, potence ratio and inbreeding depression, (2) to determine the different types of gene action of gossypol percentage and other studied traits, and (3) to study the relative importance of seed traits to gossypol percentage in seed.

\section{MATERIALS AND METHODS}

The field experiment was carried out at Sakha Agricultural Res. Station during the seasons from 2014 to 2017. Two genotypes, namely the cultivar Giza 45 (an extra long staple, extra fineness, strong lint and high fiber quality) and BBB line (an extra long staple line, characterized by high gossypol, earliness and high yield) belonging to $G$. barbadense L. were supplied by the Cotton Breeding Section of Cotton Res. Inst., ARC. Crosses between the two genotypes were made in 2014 season to produce the $F_{1}$ seeds, which were grown in the next season (2015) to produce selfed seeds of the $F_{2}$ progeny. In 2016 season, the $F_{2}$ seeds were planted to produce selfed seed of the $\mathrm{F}_{3}$ progeny. In 2017 season the seeds of the five populations $\left(\mathrm{P}_{1}, \mathrm{P}_{2}, \mathrm{~F}_{1}, \mathrm{~F}_{2}\right.$ and $\left.\mathrm{F}_{3}\right)$ were grown for evaluation. Each plot consisted of three rows, each row was $4 \mathrm{~m}$ long, $60 \mathrm{~cm}$ apart and $20 \mathrm{~cm}$ between hills. Hills were thinned to one plant / hill. Standard cultural practices were applied through out the growing seasons.

The measurements were recorded on ten guarded individual plants for the two parents, 21 individual plants of the $F_{1}, 90$ individual plants of the $F_{2}$ and 60 individual plants of the $F_{3}$ populations for the following characters:

1-Gossypol percentage in powdered seeds by the method described by the A.O.A.C. (2000).

2-Seed size represented by three scores as follows: (a) 2 is small, (b) 3 is medium and (c) 4 is large.

3-Fuzz color represented by five scores as follows: (a) 2 is white, (b) 2.5 is grey dark, (c) 3 is brown dark, (d) 3.5 is dark and (e) 4 is green.

4-Fuzz distribution on seeds represented by six scores as follows: (a) 2 is absent, (b) 2.125 is small fuzz $1 / 8$, (c) 2.25 is fuzz $1 / 4$, (d) 2.50 is fuzz $1 / 2$, (e) 2.75 is fuzz $3 / 4$ and (f) 3 is complete fuzz.

Measurement of seed characters (seed size, fuzz color and fuzz distribution) were transformed to its $\log 10)$.

5- Seed cotton yield per plant (g)

6- Lint yield per plant (g)

7- Lint percentage (L \%): Obtained from the formula: $\mathrm{L} \%=($ lint yield $/$ seed yield $) \times 100$.

8-Seed index (SI): Estimated as weight of 100 seeds in grams.

9- Lint index (LI): was calculated using the formula: (S I x L \%) / (100 - L).

\subsection{Genetic analysis}

Data for the studied traits were used to estimate means and variances for $\mathrm{P}_{1}, \mathrm{P}_{2}, \mathrm{~F}_{1}, \mathrm{~F}_{2}$ and $\mathrm{F}_{3}$ generations. Heterosis over mid-parent (MP \%) and better parent (BP \%), Potence ratio (PR) were estimated according to Smith (1952) and inbreeding depression (ID \%) were calculated as follows:

$$
\begin{aligned}
& \text { MP heterosis } \%=\left\{\left(\frac{\mathrm{F}_{1}-\overline{M P}}{\mathrm{MP}}\right) \times 100\right\} \\
& \mathrm{BP} \text { heterosis } \%=\left\{\left(\frac{\mathrm{F}_{1}-\mathrm{B} . \mathrm{P}}{\mathrm{B} . \mathrm{P}}\right) \times 100\right\} \\
& \mathrm{PR} \text { in } \mathrm{F}_{1}=[(\overline{F 1}-M P) / 1 / 2(P 2-P 1)] \\
& \mathrm{P} \mathrm{R} \text { in } \mathrm{F}_{2}=[2(\overline{F 2}-M P) / 1 / 2(P 1-P 2)] \\
& (\mathrm{ID} \%) \mathrm{F}_{2}=[[(\overline{F 1}-\overline{F 2}) / \overline{F 1}] x 100] \\
& (\mathrm{I} \mathrm{D} \%) \mathrm{F}_{3}=[[(\overline{F 1}-\overline{F 3}) / \overline{F 1}] x 100]
\end{aligned}
$$

Statistical significance of heterosis and inbreeding depression were determined by t-test using the appropriate least significant difference ( L.S.D.) as follows: L.S.D for: Mid-Parent heterosis $=\operatorname{t\alpha } \times \sqrt{3 M S E / 2 r}$ 
Better parent and inbreeding depression $=\mathrm{t} \alpha \mathrm{x}$ $\sqrt{2 M S E / r}$

The population means and variances were used to compute the scaling tests $\mathrm{C}$ and $\mathrm{D}$ to estimate the type of gene effects according to Mather and Jinks (1971).

Estimates of genetic components were estimated for five populations (five parameters model) according to Hayman (1958) using the following formulae and the calculated variance of these parameters was used to determine $(\mathrm{Sd})$ for each parameter.

$\mathrm{M}=\mathrm{F}_{2}, \mathrm{~d}=\left[\left(1 / 2 \mathrm{P}_{1}\right)-\left(1 / 2 \mathrm{P}_{2}\right)\right], \mathrm{h}=[1 / 6(4$ $\left.\mathrm{F}_{1}+12 \mathrm{~F}_{2}-16 \mathrm{~F}_{3}\right]$

$\mathrm{L}(\mathrm{d} \mathrm{x} \mathrm{d})=[1 / 3(16 \mathrm{~F} 3-24 \mathrm{~F} 2+8 \mathrm{~F} 1)]$

$\mathrm{I}(\mathrm{a} \times \mathrm{a})=\left[(\mathrm{P} 1-\mathrm{F} 2)+\frac{1}{2}(\mathrm{P} 1-\mathrm{P} 2+\mathrm{h})-\frac{1}{4} \mathrm{~L}\right]$

Where: $\mathrm{M}=$ Mean performance of $\mathrm{F}_{2}, \mathrm{~d}=$ additive effect, $\mathrm{h}=$ dominance effect, $\mathrm{L}=$ Dominance $\mathrm{x}$ Dominance interaction, $\mathrm{I}=$ Additive $\mathrm{x}$ Additive interaction.

Calculating correlation coefficient between gossypol percentage and four seed traits (seed index, seed size, fuzz color and fuzz distribution) and multiple regression analysis was carried out according to Draper and Smith (1966) to determine the best variables accounted for most variance of gossypol content in seed cotton. Data obtained were computed using Minitab software.

\section{RESULTS AND DISCUSSION}

Mean values of the studied traits, heterosis, potence ratio and inbreeding depression are presented in Table (1). The results indicated that the two parents exhibited significant difference for gossypol $\%$ and seed traits. The first parent (BBB line) exhibited higher values for gossypol $\%$, seed size and fuzz distribution than the second parent (cultivar Giza 45), while the two parents differed for fuzz color. Non-significant differences existed between the two parents for seed yield, lint yield and lint $\%$.

Concerning the $F_{1}$ generation means, seed cotton yield, lint yield and fuzz distribution were less than the means of Giza 45, while the other traits were intermediate between the two parents. Heterosis over mid parent was non-significant for all the studied traits. Moreover, negative and significant heterosis relative to the better parent was obtained for gossypol \%, seed index and seed traits. Different results were obtained by ElHelw (2002) who reported positive and highly significant heterotic effect relative to the mid parent for seed cotton yield/plant, lint yield and lint $\%$.

Potence ratio (Table 1) revealed over dominance for seed cotton yield ,lint yield, lint $\%$ and fuzz distribution of the $\mathrm{F}_{1}$ generation, while potence ratio was less than unity, indicating partial dominance for gossypol \%, seed size and fuzz colour.

The $\mathrm{F}_{2}$ generation showed the highest performance for gossypol \%, fuzz color, lint $\%$ and lint index surpassed the higher parent (BBB line). It was less than the $F_{1}$ generation and second parent (Giza 45) for yield traits.

These results are in harmony with the values of $F_{2}$ potence ratio in Table (1) , indicating over dominance of the second parent (Giza 45) for seed and lint yield, lint \% and fuzz distribution. Potence ratio (Table 1) revealed over dominance for higher gossypol percentage, seed index and lint index in the $F_{2}$ generation. Similar results were reported by El-Akheder (2001), who stated that over dominance controlled inheritance of seed cotton yield and lint yield.

Inbreeding depression was higher for seed and lint yield in the $\mathrm{F}_{2}$ generation, while it was highly significant for gossypol \%, fuzz distribution, seed index and lint index.

Concerning the $\mathrm{F}_{3}$ generation, the data in Table (1) showed that the values of mean performance of $F_{3}$ generation were the highest for gossypol $\%$ and seed index surpassed from parent BBB line, while the fuzz distribution and fuzz color were intermediate between the two parents.

Mean performance of the $\mathrm{F}_{3}$ generation for yield traits did not differ from the higher parent BBB line. These results are in harmony with inbreeding depression of the $F_{3}$ generation (Table1) with negative values, indicating that the $\mathrm{F}_{3}$ generation surpassed the higher parent (BBB line), except for fuzz distribution and lint index.

\subsection{Gene action and type of epistasis}

Results of scaling tests C and D for the studied traits are presented in Table (2). Data showed that one or both of $\mathrm{C}$ and $\mathrm{D}$ were significant for all the studied traits, indicating the presence of non allelic interaction for all the studied traits (12 out 18). Scaling tests gave trends of significance of non allelic for all the studied traits, except for seed size and fuzz colour indicatingabsence of the non allelic interaction for these two traits. 
Table (1): Mean performance, \pm standard error, heterosis \% relative to mid parent (MP), better parent (BP), potence ratio (PR) and inbreeding depression (ID) of parents, the $F_{1}$, the $F_{2}$ and $F_{3}$ generations in the cotton cross used.

\begin{tabular}{|c|c|c|c|c|c|c|c|c|c|c|}
\hline \multicolumn{2}{|c|}{ Generations } & $\begin{array}{c}\text { Gossypol } \\
\%\end{array}$ & Seed size & $\begin{array}{l}\text { Fuzz } \\
\text { colour }\end{array}$ & $\begin{array}{c}\text { Fuzz } \\
\text { distribution }\end{array}$ & $\begin{array}{c}\text { Seed } \\
\text { cotton } \\
\text { yield /Plant } \\
\text { (g) }\end{array}$ & $\begin{array}{l}\text { Lint yield } \\
\text { / Plant (g) }\end{array}$ & Lint \% & $\begin{array}{c}\text { Seed index } \\
(\mathrm{g})\end{array}$ & Lint index \\
\hline \multicolumn{2}{|c|}{$\mathbf{P}_{1}(\mathrm{BBB})$} & $0.32 \pm 0.04$ & $60.2 \pm 0$ & $30.1 \pm 0$ & $47.7 \pm 0$ & $103.4 \pm 18.89$ & $36.24 \pm 6.38$ & $34.95 \pm 1.33$ & $13.65 \pm 0.40$ & $7.33 \pm 0.32$ \\
\hline \multicolumn{2}{|c|}{$P_{2} \quad(G .45)$} & $0.21 \pm 0.02$ & $30.1 \pm 0$ & $47.7 \pm 0$ & $39.8 \pm 0$ & $97.34 \pm 12.81$ & $34.97 \pm 4.66$ & $35.82 \pm 0.64$ & $11.52 \pm 0.18$ & $5.84 \pm 056$ \\
\hline \multirow{3}{*}{$\mathbf{F}_{1}$} & MP & -12.50 & -2.61 & 5.39 & -11.12 & -14.22 & -10.29 & 3.77 & -5.47 & 5.45 \\
\hline & BP & $-26.67 * *$ & $-26.96 * *$ & $-14.06^{* *}$ & $-18.48^{* *}$ & -16.73 & -11.86 & 2.51 & $-12.83 * *$ & -5.27 \\
\hline & PR & -0.65 & -0.08 & -0.24 & -1.23 & -4.71 & -5.77 & -3.07 & -0.65 & 0.48 \\
\hline $\mathbf{F}_{2}$ & ID & $-222.68 * *$ & -4.57 & 3.62 & $10.04 * *$ & $17.55^{* *}$ & $17.68 * *$ & -0.31 & $-11.89 * *$ & $-12.11 * *$ \\
\hline \multirow{2}{*}{$\mathbf{F}_{3}$} & Mean & $0.85 \pm 0.03$ & $47.07 \pm 0.78$ & $44.30 \pm 1.02$ & $34.24 \pm 0.34$ & $103.55 \pm 5.62$ & $35.80 \pm 2.12$ & $34.26 \pm 0.46$ & $13.98 \pm 0.17$ & $7.31 \pm 0.14$ \\
\hline & ID & $-266.67 * *$ & -7.04 & -8.07 & $11.96 * *$ & $-20.26 * *$ & $-12.08 * *$ & $6.69 * *$ & $-17.49 * *$ & -5.21 \\
\hline
\end{tabular}

$*$, ** Significant at 0.05 and 0.01 levels of probability, respectively 
Table (2): Scaling test values and gene effects for the studied traits in the cotton cross used.

\begin{tabular}{|c|c|c|c|c|c|c|c|c|}
\hline \multirow[b]{2}{*}{ Traits } & \multicolumn{2}{|c|}{ Scaling test } & \multicolumn{5}{|c|}{ Gene effects } & \multirow[b]{2}{*}{ Type of epistesis } \\
\hline & $\mathbf{C}$ & D & $\begin{array}{c}\text { M } \\
\text { Mean } \\
\left(\mathbf{F}_{2}\right) \\
\end{array}$ & $\begin{array}{c}\text { d } \\
\text { (Additive) }\end{array}$ & $\begin{array}{c}\mathbf{h} \\
\text { (Dominan } \\
\text { ce) }\end{array}$ & $\begin{array}{c}\mathbf{L} \\
\text { (Dom x } \\
\text { Dom) }\end{array}$ & $\begin{array}{c}\text { I } \\
(\operatorname{Ad} \times \mathrm{x} \text { Ad) }\end{array}$ & \\
\hline Gossypol \% & $\begin{array}{l}1.99 * * \\
\pm 0.46\end{array}$ & $\begin{array}{l}1.37 * * \\
\pm 0.25\end{array}$ & $\begin{array}{l}0.75 * * \\
\pm 0.12\end{array}$ & $\begin{array}{l}\mathbf{0 . 0 5 *} \\
\pm 0.02\end{array}$ & $\begin{array}{l}-0.61 * * \\
\pm 0.24\end{array}$ & $\begin{array}{l}-0.83 \\
\pm 0.93\end{array}$ & $\begin{array}{l}-0.48 \\
\pm 0.26\end{array}$ & -- \\
\hline Seed size & $\begin{array}{l}5.69 \\
\pm 6.55\end{array}$ & $\begin{array}{c}6.00 \\
\pm 3.66\end{array}$ & $\begin{array}{l}45.98 * * \\
\pm 0.96\end{array}$ & $\begin{array}{c}15.05 * * \\
\pm 0.00\end{array}$ & $\begin{array}{l}-4.23 \\
\pm 3.34\end{array}$ & $\begin{array}{l}0.42 * * \\
\pm 11.23\end{array}$ & $\begin{array}{l}27.05 * * \\
\pm 3.27\end{array}$ & Duplicate \\
\hline Fuzz colour & $\begin{array}{c}49.01 \\
\pm 32.44\end{array}$ & $\begin{array}{c}-4.99 \\
\pm 16.61\end{array}$ & $\begin{array}{l}53.20 * * \\
\pm \mathbf{8 . 0 5}\end{array}$ & $\begin{array}{l}\mathbf{- 8 . 8 0} * * \\
\pm 0.00\end{array}$ & $\begin{array}{c}13.59 \\
\pm 16.38\end{array}$ & $\begin{array}{l}-72.00 * \\
\pm 64.85\end{array}$ & $\begin{array}{c}-6.11 \\
\pm 18.17\end{array}$ & --- \\
\hline Fuzz distribution & $\begin{array}{c}-25.34 * * \\
\quad \pm 0.00\end{array}$ & $\begin{array}{c}-20.52 * * \\
\pm 0.00\end{array}$ & $\begin{array}{l}34.98 * * \\
\pm 0.46\end{array}$ & $\begin{array}{l}3.95 * * \\
\pm 0.00\end{array}$ & $\begin{array}{l}4.59 * * \\
\pm 1.47\end{array}$ & $\begin{array}{c}6.43 \\
\pm 4.96\end{array}$ & $\begin{array}{c}17.36 * * \\
\pm 0.00\end{array}$ & Complementary \\
\hline $\begin{array}{l}\text { Seed cotton yield / } \\
\text { Plant (g) }\end{array}$ & $\begin{array}{l}\mathbf{- 8 8 . 9 8} * * \\
\pm \mathbf{3 2 . 6 0}\end{array}$ & $\begin{array}{l}71.48 * * \\
\pm 32.79\end{array}$ & $\begin{array}{c}\text { 70.99** } \\
\pm 3.52\end{array}$ & $\begin{array}{c}3.03 \\
\pm 11.41\end{array}$ & $\begin{array}{c}-76.76 * * \\
\pm 17.67\end{array}$ & $\begin{array}{l}213.96 * * \\
\pm 47.96\end{array}$ & $\begin{array}{l}-56.43 * \\
\pm 29.55\end{array}$ & Duplicate \\
\hline Lint yield /plant ( g) & $\begin{array}{l}-29.92 * * \\
\pm 11.92\end{array}$ & $\begin{array}{c}19.41 * * \\
\pm 11.90\end{array}$ & $\begin{array}{c}26.29 * * \\
\pm 1.35\end{array}$ & $\begin{array}{c}0.64 \\
\pm 3.95\end{array}$ & $\begin{array}{c}-21.59 * * \\
\pm 6.70\end{array}$ & $\begin{array}{c}65.77 * * \\
\pm 18.27\end{array}$ & $\begin{array}{c}-16.66 * \\
\pm 10.49\end{array}$ & Duplicate \\
\hline Lint \% & $\begin{array}{c}3.11 \\
\pm 2.55\end{array}$ & $\begin{array}{c}-7.38 * * \\
\pm 2.46\end{array}$ & $\begin{array}{c}\text { 36.83** } \\
\pm 0.37\end{array}$ & $\begin{array}{l}-0.44 \\
\pm 0.74\end{array}$ & $\begin{array}{c}6.77 * * \\
\pm 1.51\end{array}$ & $\begin{array}{c}-14.0 * * \\
\pm 4.32\end{array}$ & $\begin{array}{l}4.57 * \\
\pm 2.11\end{array}$ & Duplicate \\
\hline Seed index (g) & $\begin{array}{l}4.28 * * \\
\pm 0.84\end{array}$ & $\begin{array}{l}4.12 * * \\
\pm 0.83\end{array}$ & $\begin{array}{c}13.31 * * \\
\pm 0.12\end{array}$ & $\begin{array}{l}1.06^{*} \\
\pm 0.22\end{array}$ & $\begin{array}{c}-2.72 * * \\
\pm 0.53\end{array}$ & $\begin{array}{l}-0.22 \\
\pm 1.48\end{array}$ & $\begin{array}{c}0.09 \\
\pm 0.67\end{array}$ & - \\
\hline Lint index & $\begin{array}{l}4.09 * * \\
\pm 0.94\end{array}$ & $\begin{array}{c}0.48 \\
\pm 0.90\end{array}$ & $\begin{array}{c}7.79 * * \\
\pm 0.11\end{array}$ & $\begin{array}{l}0.75 * \\
\pm 0.32\end{array}$ & $\begin{array}{l}0.72 * \\
\pm 0.48\end{array}$ & $\begin{array}{l}4.80 * * \\
\pm 1.36\end{array}$ & $\begin{array}{c}1.85 * * \\
\pm 0.83\end{array}$ & Complementary \\
\hline
\end{tabular}

*, ** Significant at 0.05 and 0.01 levels of probability, respectively 
Data in Table (2) showed that the mean effects of the $\mathrm{F}_{2}$ generation (M) were highly significant for all the studied traits, suggesting that these traits had quantitative inheritance. Results showed that the additive gene effects (d) were non-significant for seed and lint yield as well as lint percentage. It also indicated that additive gene effects were significant or highly significant for gossypol \%, seed traits, seed index and lint index. The data in Table (2) showed that dominance gene effects (h)were highly significant or significant for all traits, except for seed size and fuzz color. Improvement of these traits could be achieved through recurrent selection (Singh and Naryaran, 2000). These results are in harmony with those obtained by Abou El-Yazid et al. (2008).

The type of epistasis dominance $\mathrm{x}$ dominance (L) was positive and significant for most studied traits, except for gossypol \%, fuzz distribution and seed index. While additive $\mathrm{x}$ additive (I) was significant for seed size and fuzz distribution, seed yield, lint yield, lint $\%$ and lint index.

Data in Table (2) showed that duplicated epistasis for seed size, seed yield, lint yield and lint\%; suggesting a duplicate interaction due to little heterotic effects. The results showed complementary type of epistasis for fuzz distribution and lint index, indicating a complementary nature between dominance and dominance $\mathrm{x}$ dominance due to increase of heterotic effects.

\subsection{The relationship between seed characters and gossypol percentage}

Table (3) showed that the relationship between gossypol \% and fuzz distribution was negative with highly significant correlation. The same was true between seed index and fuzz color, between seed size and fuzz color and between fuzz colour and fuzz distribution for all generations as bulk. While there was a positive and significant correlation between seed index and seed size and also between seed size and fuzz distribution. Asghar and Iqbal (2012) did not find any relative contributor between gossypol and seed cotton yield.

\subsection{The prediction of gossypol content in cotton seed}

The multiple regression analysis presented in Table (4) revealed that four variables model is the best equation to determine the prediction of gossypol $\%$, mean variance of the $\mathrm{F}_{3}$ and all generations as bulk were highly significant, while the equation determining for the two generations the $F_{1}$ and the $F_{2}$ showed that the four variables model of gossypol \% prediction were not the best equation because they had non-significant values.

Table (5) showed the coefficients of determination of the best variables in the $\mathrm{P}_{1}, \mathrm{P}_{2}$, $\mathrm{F}_{1}, \mathrm{~F}_{2}, \mathrm{~F}_{3}$ and all generations as bulk. Regarding the two parents $\mathrm{P}_{1}$ and $\mathrm{P}_{2}$, seed index was considered to have direct effect on gossypol \%, as it was responsible for $2.4 \%$ and $2.0 \%$ reduction in gossypol \% variance, while excluded variables were responsible for $97 \%$ and $98 \%$ for the two parents, respectively.

The equation predictor for $\mathrm{P}_{1}$ (BBB line) is: $\hat{Y}=0.654-0.024$ seed index

The equation predictor for $\mathrm{P}_{2}($ Giza 45) is: $\hat{\mathrm{Y}}=-0.02+0.02$ seed index

For the $F_{1}$ generation, seed index was the highest contributor for gossypol \% variance. It was responsible for $\% 0.3$ reduction of the total gossypol \% variance. The other contributors were seed size and fuzz distribution. which were responsible for \% 0.2 of the total gossypol \% variance. While fuzz color was a less contributor of total gossypol \% variance as it was responsible for $0.01 \%$ of the total variance. Four contributors were responsible for reduction 0.07 $\%$ of the total gossypol \% variance.

The prediction equation for the $\mathrm{F}_{1}$ generation is: $\hat{\mathrm{Y}}=0.226+0.003$ seed index +0.002 seed size 0.0001 fuzz color.

Regarding the two generations the $\mathrm{F}_{2}$ and $F_{3}$, the results in Table (5) indicated that seed index was the highest contributor of the total gossypol variance. It was responsible for $9.2 \%$ and $4 \%$ of the total variance for the $\mathrm{F}_{2}$ and the $\mathrm{F}_{3}$ generations,respectively. While fuzz distribution was the second contributor of total gossypol $\%$ variance. It was responsible $5.1 \%$ and $3.2 \%$ of total variance for the $F_{2}$ and the $F_{3}$ generations, respectively.

The data in Table (5) showed that the variable of fuzz color was less contributor for gossypol \% variance. It was responsible for $0.01 \%$ and $0.04 \%$ for the $\mathrm{F}_{2}$ and $\mathrm{F}_{3}$ generations, respectively. The four traits represented $14.9 \%$ and $8.3 \%$ of the total gossypol \% variance, while the excluded variables represented $85.1 \%$ and $91.7 \%$ for the $F_{2}$ and the $F_{3}$ generations, respectively. 
Table (3): Correlation coefficients between gossypol \% and seed traits.

\begin{tabular}{|c|c|c|c|c|}
\hline Traits & Seed index & Gossypol \% & Seed size & Fuzz colour \\
\hline Gossypol \% & 0.039 & - & - & - \\
\hline Seed size & $0.419 * *$ & -0.098 & - & - \\
\hline Fuzz colour & $-0.227 *$ & 0.084 & $-0.268 * *$ & \\
\hline Fuzz distribution & 0.089 & $-0.272 * *$ & $0.347 * *$ & $-0.343 *$ \\
\hline
\end{tabular}

*, ** Significant at 0.05 and 0.01 levels of probability, respectively

Table (4): Analysis of variance for multiple linear regression for all generations.

\begin{tabular}{|c|c|c|c|c|c|c|c|c|c|c|c|c|}
\hline \multirow{2}{*}{ Variance } & \multicolumn{2}{|c|}{$\mathbf{P}_{1}$} & \multicolumn{2}{|c|}{$\mathbf{P}_{2}$} & \multicolumn{2}{|l|}{$\mathrm{F}_{1}$} & \multicolumn{2}{|c|}{$\mathbf{F}_{2}$} & \multicolumn{2}{|l|}{$\mathbf{F}_{3}$} & \multicolumn{2}{|c|}{$\begin{array}{c}\text { All } \\
\text { generations }\end{array}$} \\
\hline & MS & df & M.S & df & MS & df & MS & df & MS & df & MS & df \\
\hline Regression & 0.009 & 1 & 0.001 & 1 & 0.001 & 4 & 1.49 & 4 & 0.113* & 4 & $3.015 * *$ & 4 \\
\hline Residual & 0.012 & 8 & 0.003 & 8 & 0.0004 & 16 & 1.17 & 85 & 0.033 & 55 & 0.568 & 186 \\
\hline
\end{tabular}

Table (5): Coefficient of determination predicted for gossypol percentage in cotton seed and seed traits in all generations.

\begin{tabular}{|c|c|c|c|c|c|c|}
\hline & $P_{1}(\mathrm{BBB})$ & $P_{2}(G .45)$ & $\mathbf{F}_{1}$ & $\mathbf{F}_{2}$ & $\mathbf{F}_{3}$ & $\begin{array}{c}\text { All generations as } \\
\text { bulk }\end{array}$ \\
\hline Constant & 0.654 & 0.020 & 0.226 & 3.57 & 2.07 & 2.23 \\
\hline Variables & $P_{1}(\mathrm{BBB})$ & $P_{2}(G .45)$ & $\mathbf{F}_{1}$ & $\mathbf{F}_{2}$ & $\mathbf{F}_{3}$ & $\begin{array}{c}\text { All generations as } \\
\text { bulk }\end{array}$ \\
\hline Seed index & -0.024 & 0.020 & 0.003 & -0.092 & -0.041 & -0.006 \\
\hline Seed size & ---- & ---- & 0.002 & 0.005 & 0.006 & 0.012 \\
\hline Fuzz colour & --- & --- & 0.0001 & -0.001 & 0.004 & -0.001 \\
\hline $\begin{array}{c}\text { Fuzz } \\
\text { distribution }\end{array}$ & --- & --- & -0.002 & -0.051 & -0.032 & -0.055 \\
\hline $\begin{array}{c}\text { Total of } \\
\text { variance }\end{array}$ & 0.024 & 0.020 & 0.007 & 0.149 & 0.083 & 0.074 \\
\hline $\begin{array}{l}\text { Excluded } \\
\text { variables }\end{array}$ & 0.976 & 0.98 & 0.993 & 0.851 & 0.917 & 0.926 \\
\hline
\end{tabular}


The prediction equation for $\mathrm{F}_{2}$ generation is: $\hat{Y}=3.57-0.092$ seed index +0.005 seed size -0.0008 fuzz color - 0.051 fuzz distribution.

The predicted equation for the $\mathrm{F}_{3}$ generation is: $\hat{\mathrm{Y}} \%=2.07-0.041$ seed index +0.006 seed size +0.0038 fuzz color -0.0316 fuzz distribution.

Concerning all generations as bulk, the data in Table (5) showed that fuzz distribution was the highest contributor for the total gossypol \% variance. It was responsible for $5.5 \%$ for total gossypol \% variance.

Second contributor was seed size.It was responsible for $1.20 \%$, seed index was the third contributor. It was responsible for $0.6 \%$ for the total variance of the total gossypol $\%$, while fuzz colour was the forth contributor. It was responsible for $0.07 \%$ of the total gossypol \% variance. The four variables responsible for 7.4 $\%$ of total variance, while the excluded variables represented $92.6 \%$ of the total variance of gossypol \%. Moreover, there were other variables, which were responsible for gossypol percentage in seeds. The predicted equation for all generations as bulk is:

$\hat{\mathrm{Y}}=2.23-0.0057$ seed index +0.0118 seed size -0.0007 fuzz color -0.055 fuzz distribution.

\section{Conclusion}

From the results presented in this study, it could be concluded that additive and dominance as well as some types of epistasis effects played important roles in the inheritance of most studied traits. Negative and significant correlations were obtained between gossypol $\%$ and fuzz distribution, seed index and fuzz colour, seed size and fuzz color. It could be concluded that fuzz distribution was the highest contributor for total variance of gossypol percentage in all generations.

\section{REFERENCES}

Abou EL-Yazied M.A., Abd EL- Bary A.M.R. and Allam M.A.M. (2008). Genetic studies of some quantitative traits in two cotton crosses ( $G$. barbadense L.).Egypt .J. Agric., Res. 86(4) 1463-1475.

A.O.A.C. (2000). Official Method of Analysis Association of Official Chemists, $18^{\text {th }}$ ED., Pub. International, Maryland, USA.

Asghar T.M. and Iqbal M.Z. (2012) .Inheritance of seed cotton yield and related traits in cotton ( $G$. hirsutum L.) . Pak. J. Bot., 44(6): 2027-2031.
Draper N.R. and Smith H. (1966). Applied regression analysis .John Wiley and Sons (Pub.), Inc., NewYork.407pp.

El-Akhedar A .A .A .(2001). Evaluation of some cotton crosses for earliness and economical traits .Ph.D Thesis,Fac. Agric. Kafr El- Sheikh Tanta Univ., Egypt.

El -Disouqui A.E. and Zeina A.M. (2001). Estimates of some genetic parameters and gene action for yield and yield components in cotton. J. Agric. Sci. . Mansoura Univ., 6(6): 3401-3409.

El-Disouqui A.E., Abo-Sen Z.F. and Abo-Arab A.R. (2000). Genetic behavior of yield and its components in Egyptian cotton. J. Agric. Sci. Masoura Univ., 25. (7): 38313840.

El-Helw S.S. H. (2002). Genetic parameters of some economic characters in the extra long cotton cross (Giza 68 x Sea Island). J. Agric. Sci. Mansoura Univ., 27. (12): 2011-2020.

Hayman B.I. (1958). The separation of epistatic from additive and dominance variation in generation means. Heredity , 12: 371- 90.

Lusas E.W. and Jividen G.M. (1987). Glandless cottonseed: A review of the first 25 years of processing and utilization research. J. Am Oil chem., 64: 839 -854.

Mather K. and Jinks J. L. (1971). Biometrical genetics (2 ${ }^{n d}$ Ed.) Chapman and Hall, (Pub.) London, UK.

Mohamed A. S. (2003). Studies on naturally brown colored cotton. Egypt J.Appl. Sci.18 (8). 148-157.

Mohamed A. S. and Hegazy E. M. (2008). Chemical composition of the seeds and meals of some Egyptian cotton varieties and possible contamination with mycotoxins. Egypt. J. Agric. Res. 86 (3): 1069-1079.

Mohamed A. A. (2015). Biometrical and genetic estimates of yield and seed characteristics in some Egyptian cotton crosses. M.Sc. Thesis, Fac. Agric., Cairo, Univ., Egypt, $74 \mathrm{pp}$.

Nazmey M.N.A. (2012). Genetical studies on some quantitative traits in a long staple cotton cross (G. barbadense L.). Egypt. J. Appl. Sci., 27 (2) 30-38.

Singh L. P. and Narayanan S.S. (2000). Biomaterial Techniques in plant breeding . Klyani Publishers, New, Delhi, 2 nd Ed. 
Smith H . H. (1952). Fixing transgressive vigor in nicotine heterosis. Iowa state college Press, Ames, Iowa, USA.

Soliman Y.A.M. (2003). Studies on some quantitative characters in some intraspecfic cotton crosses. Ph.D. Thesis,
Fac. Agric., Kafer EL- Sheikh, Tanta Univ., Egypt.

Sultan A. M .M. (2017). Genetic parameters for seed oil content, yield components and fiber quality in an Egyptian cotton hybrid. Egypt. J. Plant Breed., 21 (3): 595-603.

السلوك الوراثي لمحتوى الجوسيبول في بذرة القطن وصفات البذرة ومكونات المحصول فى هجين من القطن المصري

\author{
عزيزة محمد كحم سلطان \\ معهد بحوث القطن - مركز البحوث الزر اعية ـ مصر
}

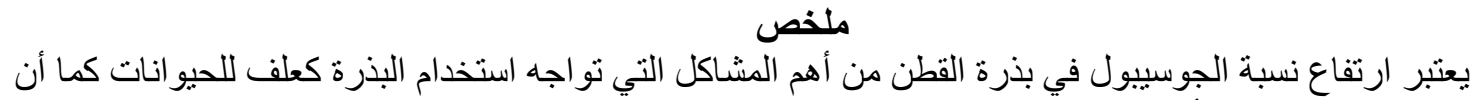

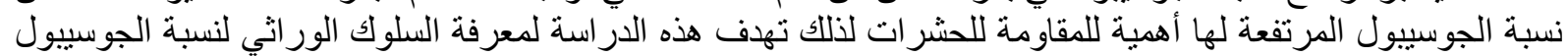

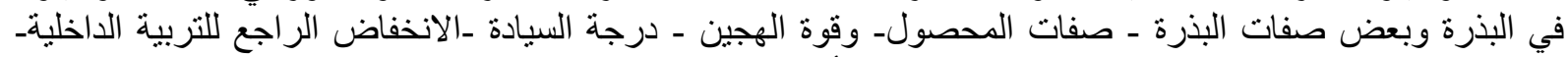

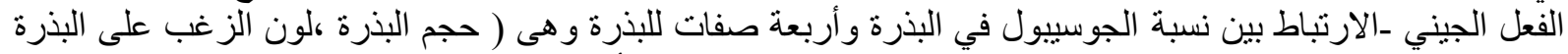

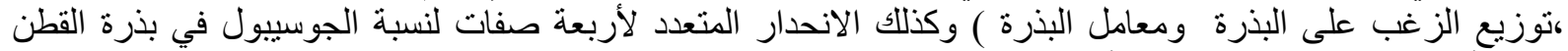

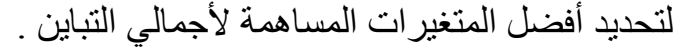

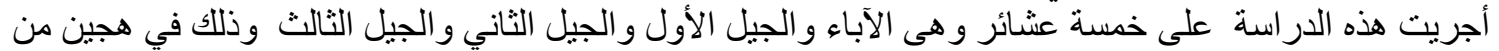

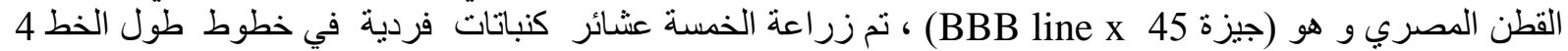

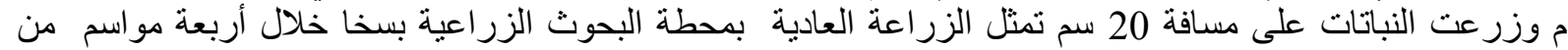

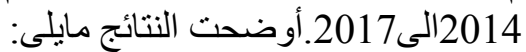

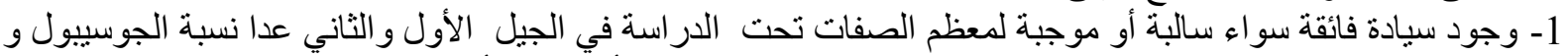

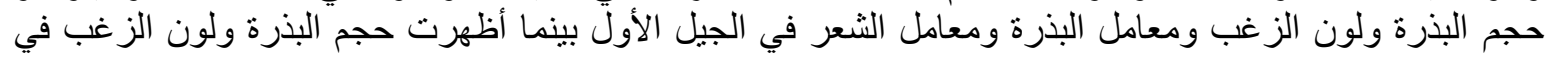

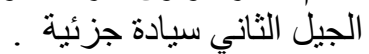

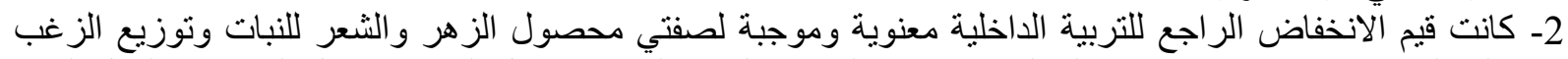

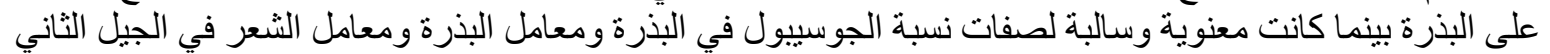

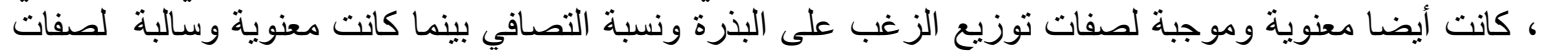

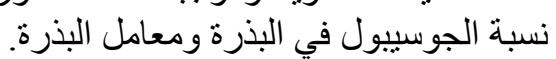

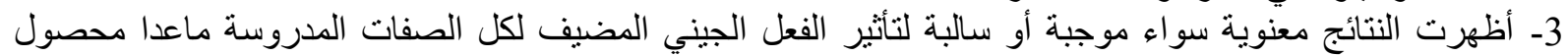

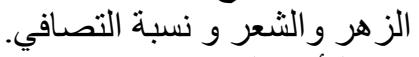

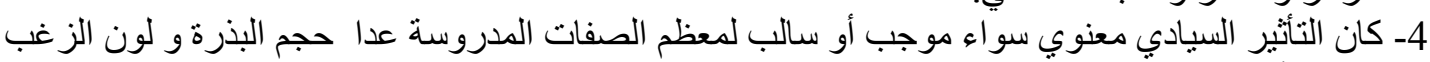

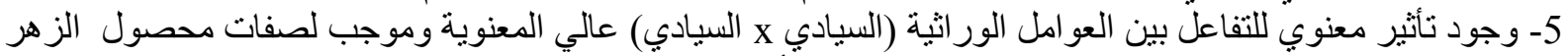

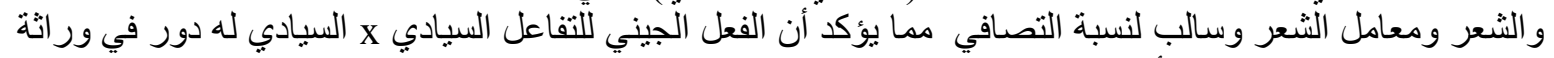

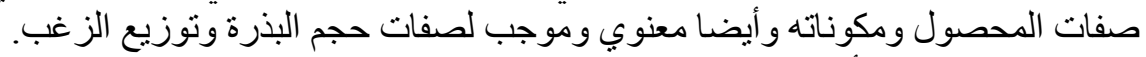

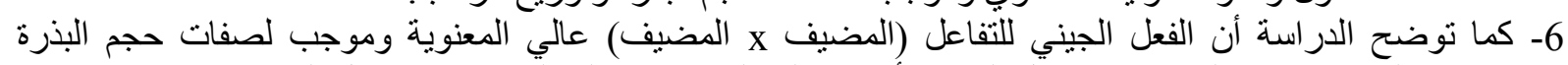

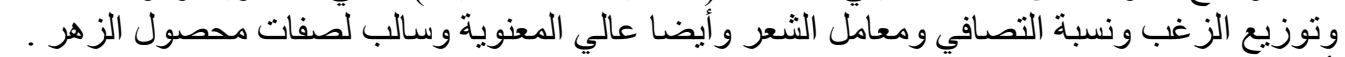

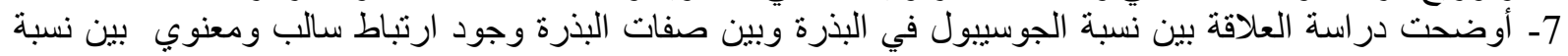

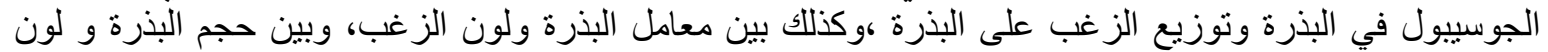

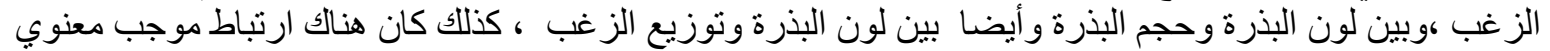

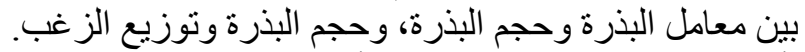

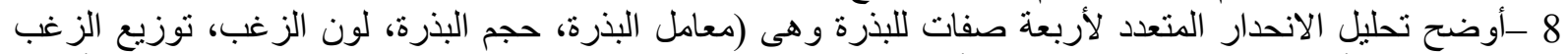

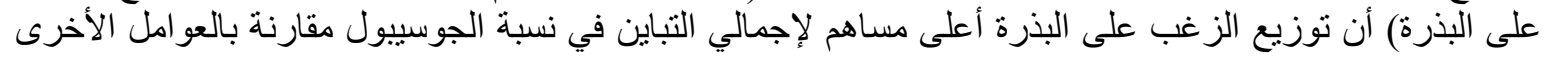
تحت الدر استة. 